\title{
KONTRIBUSI SUMBER DAYA MANUSIA PETANI PEREMPUAN DALAM KEHIDUPAN PERTANIAN DI DESA
}

\author{
Ruri Purnamawati ${ }^{1}$
}

\begin{abstract}
Abstrak
Penelitian ini bertujuan untuk mendeskripsikan wujud dan proses kontribusi SDM petani perempuan dalam kehidupan pertanian di Desa Tegalrejo, Kecamatan Banyuurip, Kabupaten Purworejo. Fenomena menunjukkan bahwa petani perempuan memiliki kontribusi yang cukup besar dalam menopang ekonomi keluarga. Oleh sebab itu penelitian ini juga ingin mengetahui faktor pendukung dan penghambat dalam kontribusi tersebut.

Penelitian ini menggunakan pendekatan kualitatif deskriptif. Informan penelitian ini adalah petani perempuan yang ada di Desa Tegalrejo. Informan diambil melalui teknik Snowball sampling, informasi diperoleh dari satu informan ke informan lain hingga data jenuh. Adapun teknik keabsahan datanya adalah menggunakan Triangulasi. Teknik analisis data dibagi dalam empat tahapan yaitu: 1. Pengumpulan data, 2. Reduksi data, 3. Penyajian data, dan 4. Penarikan kesimpulan serta kemudian dipadukan dengan salah satu analisis gender yakni Analisis Harvard yang terdiri atas tiga elemen pokok yaitu profil aktivitas, profil akses, dan profil kontrol.

Hasil penelitian pada kontribusi SDM petani perempuan di Desa Tegalrejo ini adalah terdapat enam wujud kontribusi SDM petani perempuan, yaitu kontribusi keuangan, kontribusi kepercayaan memperoleh kapital, kontribusi untuk menjalin hubungan sosial yang harmonis, kontribusi melanjutkan tradisi bertani/kearifan lokal, dan kontribusi tenaga kerja pertanian yang ulet dan disiplin, serta kontribusi ide/pikiran. Adapun proses kontribusi tersebut dibagi menjadi dua yaitu kontribusi dalam rumah tangga petani dan kontribusi dalam pertanian. Faktor pendukung yang mempengaruhi kontribusi SDM petani prempuan ini adalah: himpitan ekonomi; banyaknya kegiatan sosial yang diikuti; kerjasama yang harmonis antar sesama petani perempuan; interaksi yang terjalin dengan baik antara petani perempuan dengan pihak-pihak yang mendukung kegiatan pertanian; dan modal sosial yang dimiliki petani perempuan, sedangkan faktor penghambatnya adalah: rasa percaya diri yang rendah; fisik lemah; beban kerja ganda; posisi perempuan yang termarginalkan dalam pengambilan keputusan dalam ranah publik pertanian; serta akses dan kontrol yang rendah terhadap sumber daya pertanian yang ada.
\end{abstract}

Kata Kunci: Petani Perempuan, SDM, Kehidupan Masyarakat Pertanian.

\footnotetext{
${ }^{1}$ Penulis adalah alumni Program Studi Pendidikan Sosiologi, FISE, Universitas Negeri Yogyakarta
} 


\section{A. Pendahuluan}

Petani

perempuan

merupakan sosok yang patut diperhitungkan. Seorang perempuan yang telah bersedia memikul beban kerja ganda dalam kehidupannya, yakni peran domestik/privat sekaligus peran publik. Peran domestik yakni peran utama seorang perempuan di dalam rumah tangga. Mengasuh anak, mengurus rumah tangga, mempersiapkan sekolah adalah beberapa dari sekian banyak tugas yang menjadi kewajiban mereka di rumah. Terlebih lagi ketika ia bekerja di luar rumah, semisal petani, maka akan lebih banyak lagi peran yang harus mereka lakukan.

Berdasarkan

Laporan

Perkembangan Pencapaian Tujuan Pembangunan Milenium Indonesia, keikutsertaan kaum perempuan dalam kegiatan pertanian (jumlah petani perempuan) kini menunjukkan adanya peningkatan. ${ }^{2}$ Tertulis di dalamnya bahwa kontribusi perempuan dalam kegiatan non pertanian mengalami penurunan di awal tahun 2002, sehingga mulai saat itu sektor pertanian mulai dipadati oleh perempuan. Begitu juga yang terjadi di Desa Tegalrejo, sebuah kawasan permukiman yang mayoritas penduduknya bergantung pada sektor pertanian dan banyak kaum perempuan di desa tersebut yang turut bekerja di sawah.

\footnotetext{
2 Laporan Perkembangan Pencapaian Tujuan Pembangunan Milenium Indonesia, dikutip dari makalah Mendorong Kesetaraan Gender dan Pemberdayaan Perempuan. Tersedia pada www.ginandjar.com. Diakses pada 29 Oktober 2008.
}

Fakta di lapangan menunjukkan bahwa marginalisasi lebih mendesak kaum perempuan dibandingkan laki-laki karena pola pembagian kerja dalam rumah tangga menempatkan perempuan untuk menanggung beban lebih besar pada tugas-tugas domestik. ${ }^{3}$ Sebagai seorang petani perempuan, kondisi tersebut tentu mereka alami dalam kehidupan sehari-hari, sehingga muncul anggapan masyarakat bahwa petani perempuan dekat dengan beban kerja ganda sekaligus kemiskinan. Kemiskinan yang melekat pada petani penggarap (gurem) merupakan kemiskinan alamiah sekaligus kemiskinan struktural. Mereka terpinggirkan akibat distribusi dan pengelolaan sumber daya alam yang tidak dapat mendukung kehidupannya. ${ }^{4}$

Indonesia sebagai negara agraris dimana $60 \%$ penduduknya bergantung pada sektor pertanian, itu artinya $60 \%$ penduduk Indonesia berprofesi sebagai petani. Akan tetapi selama ini pula wacana pertanian tidak menempatkan petani perempuan sebagai subjek dari proses pertanian. Padahal dalam kenyataannya hampir seluruh proses pertanian itu sendiri di kerjakan oleh perempuan, mulai dari menangkar bibit, menyebar benih hingga masa panen, perempuan berperan penuh di

\footnotetext{
${ }^{3}$ Ratih Dewayanti dan Erna Ermawati Chotim, Marginalisasi dan Eksploitasi Perempuan Usaha Mikro di Perdesaan Jawa, Bandung: Akatiga, 2004, hlm. Xv.

${ }^{4}$ Ja Noertjahyo, Dari Ladang Sampai Kabinet: Menggugat Nasib Petani, Jakarta: Penerbit Buku Kompas, 2005, hlm. 15
} 
dalamnya. Hal ini membuktikan bahwa perempuan bertanggungjawab penuh terhadap kelangsungan pertanian dan kelangsungan pangan keluarga serta negara itu sendiri.

Petani perempuan yang akan menjadi objek kajian oleh peneliti adalah petani perempuan yang berada di Desa Tegalrejo, yakni sebuah desa di Kabupaten Purworejo, Jawa Tengah, dengan kehidupan agrarisnya yang masih begitu kental hingga sekarang. Banyaknya kaum perempuan yang turun ke sawah telah memberikan inspirasi tersendiri bagi peneliti untuk mengungkap kinerja mereka dalam kegiatan pertanian. Pembagian tugas dalam pertanian antara laki-laki dan perempuan ternyata telah tersamarkan akibat kendala keuangan. Selain terjadi bias dalam pembagian kerja, ternyata upah yang diterima petani perempuan tidak seimbang dengan pekerjaan mereka, mereka juga masih terpinggirkan dalam hal pengambilan keputusan di sektor publik.

Keikutsertaan petani perempuan dalam sektor publik salah satunya dapat dilihat dalam kegiatan penyuluhan pertanian karena kegiatan penyuluhan menjadi hak seluruh masyarakat tani, akan tetapi pada kenyataannya petani perempuan kurang dilibatkan dalam kegiatan penyuluhan tersebut. Petani perempuan hanya sebagai pelaku kegiatan pertanian saja tanpa diberikan kesempatan untuk turut meningkatkan pengetahuan tentang pertanian dan menyampaikan aspirasinya.

Hal lain yang menarik minat peneliti adalah mengenai modal sosial yang dimiliki oleh petani perempuan di Desa Tegalrejo. Modal sosial yang mereka miliki merupakan nilai lebih yang memberikan kontribusi besar terhadap kehidupan pertanian di Desa Tegalrejo. Sayangnya potensi petani perempuan ini belum diakui secara maksimal serta masih banyak lagi hak-hak lainnya dalam kehidupan sehari-hari maupun dalam bidang pertanian yang belum mampu diakses oleh petani perempuan sehingga menjadi salah satu penghambat untuk berkontribusi secara maksimal dalam kegiatan pertanian ini.

Adapun tujuan yang hendak dicapai dalam penelitian ini adalah sebagai berikut: mendeskripsikan wujud dan proses kontribusi SDM (Sumber Daya Manusia) petani perempuan dalam kehidupan pertanian di Desa Tegalrejo, Kecamatan Banyuurip, Kabupaten Purworejo; 2) mengetahui faktor pendukung dan penghambat petani perempuan dalam berkontribusi di bidang pertanian di Desa Tegalrejo, Kecamatan Banyuurip, Kabupaten Purworejo.

\section{B. Kerangka Teori}

1. SDM (Sumber Daya Manusia) SDM (Sumber Daya Manusia) merupakan salah satu sumber daya yang terdapat dalam 
organisasi, meliputi semua orang yang melakukan aktivitas. Secara umum, sumber daya yang terdapat dalam suatu organisasi dapat dikelompokkan menjadi dua macam, yakni: Sumber Daya Manusia (human resource), dan Sumber Daya Non-manusia (nonhuman resource). Sumber daya non manusia ini meliputi modal, mesin, teknologi, bahan-bahan (material), dan lain-lain. ${ }^{5}$

Secara umum, dari keseluruhan sumber daya yang tersedia dalam suatu organisasi, baik organisasi publik maupun swasta, maka sumber daya manusialah yang paling penting dan paling menentukan. ${ }^{6}$

Sumber daya manusia merupakan satu-satunya sumber daya yang memiliki akal, perasaan, keinginan, kemampuan, ketrampilan, pengetahuan, dorongan, daya dan karya. Satusatunya sumber daya yang memiliki ratio, rasa dan karsa. Semua potensi sumber daya manusia sangat berpengaruh terhadap upaya organisasi dalam pencapaian tujuannya. Meskipun teknologi semakin maju dan informasi berkembang pesat, namun jika tanpa sumber daya manusia maka akan sulit bagi organisasi untuk mencapai tujuannya. Sebuah lahan pertanian dapat diumpamakan sebagai medan organisasi, itu artinya petani sebagai sumber daya manusia yang berperan penting di dalamnya. Sebaik apapun

\footnotetext{
${ }^{5}$ Faustino Cardoso Gomes, Manajemen Sumber Daya Manusia, Yogyakarta: Andi, 2003, hlm. 1 ${ }^{6}$ Ibid., hlm. 2
}

perumusan tujuan dan rencana organisasi maka akan sia-sia hasilnya apabila sumber daya manusianya tidak diperhatikan bahkan ditelantarkan.

\section{SDM Petani Perempuan}

Petani perempuan, merupakan jenis pekerjaan sebagai petani yang ditekuni oleh perempuan. Ketika perempuan memutuskan untuk menjadi seorang petani, berarti mereka telah siap menanggung beban kerja ganda, yakni sebagai ibu rumah tangga sekaligus bekerja di luar rumah (sebagai petani). Perbaikan teknologi pertanian yang meliputi penggunaan teknologi mekanis, penggunaan varietas unggul yang seragam, serta masa tanam yang serempak pada akhirnya justru mengakibatkan penurunan kesempatan kerja bagi perempuan. Perempuan kehilangan kesempatan berburuh tani pada kegiatan menanam, menyiang, dan panen. ${ }^{7}$ Oleh karena itu perempuan memerlukan alternatif pekerjaan lain diluar kegiatan pertanian. Namun, banyaknya penduduk yang membutuhkan pekerjaan dan sempitnya lapangan pekerjaan membuat beberapa kaum perempuan terpaksa turun ke sawah mengolah lahan pertanian, terlebih lagi di Desa Tegalrejo belum terdapat sektor industri yang

\footnotetext{
${ }^{7}$ Ken Suratiyah, Pembangunan Pertanian dan Peranan Wanita di Pedesaan Yogyakarta dan Bali, Yogyakarta: Pusat Penelitian Kependudukan, 1991, dalam Ken Suratiyah, dkk, Dilema Wanita Antara Industri Rumah Tangga dan Aktivitas Domestik. Yogyakarta: Aditya Media, 1996, hlm. 20
} 
Peran Lembaga Swadaya Masyarakat

sekiranya dapat menampung mayoritas kaum perempuan.

Proses

peningkatan

kesejahteraan masyarakat dapat diterapkan melalui berbagai pendekatan, salah satu diantaranya adalah pemberdayaan masyarakat. ${ }^{8}$ Peningkatan kesejahteraan masyarakat petani juga dapat dilakukan melalui pemberdayaan tersebut. Istilah keberdayaan dalam konteks masyarakat adalah kemampuan individu-individu yang bersenyawa dengan individuindividu lainnya dalam masyarakat untuk membangun keberdayaan masyarakat yang bersangkutan. ${ }^{9}$

Kaum petani perempuan miskin adalah sasaran yang tepat untuk dilakukan pemberdayaan. Memberdayakan masyarakat adalah upaya memperkuat unsur-unsur keberdayaan itu untuk meningkatkan harkat dan martabat lapisan masyarakat yang berada dalam kondisi tidak mampu dengan mengandalkan kekuatannya sendiri sehingga dapat keluar dari perangkap kemiskinan dan keterbelakangan, atau proses memampukan dan memandirikan masyarakat. ${ }^{10}$ Petani perempuan diajarkan untuk dapat mandiri dan mampu mengandalkan

\footnotetext{
8 Anwar. Manajemen Pemberdayaan Perempuan: Perubahan Sosial Melalui Pembelajaran Vocational Skill pada Keluarga Nelayan, Bandung: Alfabeta, hlm. 1

${ }^{9}$ Ibid.

${ }^{10}$ Ginandjar Kartasasmita, Kemiskinan, 1997, hlm. 74 dalam Anwar. Manajemen Pemberdayaan Perempuan: Perubahan Sosial Melalui Pembelajaran Vocational Skill pada Keluarga Nelayan, Bandung: Alfabeta, hlm. 1
}

kekuatannya melalui manajemen pemberdayaan perempuan, sehingga mereka mampu untuk bangkit meningkatkan kesejahteraan diri, keluarga dan masyarakat melalu kontribusinya dalam kegiatan pertanian.

\section{Gender dalam Pertanian}

Trisakti Handayani dan Sugiarti menekankan bahwa untuk memahami kata gender, harus dibedakan dengan kata seks atau jenis kelamin. Seks adalah pembagian jenis kelamin antara laki-laki dan perempuan yang secara biologis memiliki perbedaan dan ciri-ciri sendiri. Secara biologis alat-alat biologis tersebut melekat pada laki-laki dan perempuan selamanya, fungsinya tidak dapat dipertukarkan. Secara permanen tidak berubah dan merupakan ketentuan biologis atau ketentuan Tuhan (kodrat). ${ }^{11}$

Konsep gender adalah sifat yang melekat pada kaum laki-laki dan perempuan yang dibentuk oleh faktor-faktor sosial maupun budaya, sehingga lahir beberapa anggapan tentang peran sosial dan budaya laki-laki dan perempuan. Oleh karena itu gender dapat diartikan sebagai konsep sosial yang membedakan (dalam arti memilih atau memisahkan) peran antara laki-laki dan perempuan. ${ }^{12}$

\footnotetext{
${ }^{11}$ Trisakti Handayani dan Sugiarti, Konsep dan Teknik Penelitian Gender, Malang: UMM Press, 2006, hlm. 4.

${ }^{12}$ Ibid, hlm. 5
} 
Perbedaan fungsi dan peran laki-laki dan perempuan ini tidak ditentukan karena latar belakang keduanya terdapat perbedaan biologis atau kodrat, tetapi dibedakan atau dipilah menurut kedudukan, fungsi dan peranan masing-masing dalam berbagai bidang kehidupan dan pembangunan, termasuk dalam kegiatan pertanian.

Kegiatan pertanian saat ini pun masih memandang perempuan hanya sebatas modal saja, tanpa ada timbal balik yang pantas untuk kontribusi petani perempuan tersebut. Pembagian tugas yang tidak berimbang, peran ganda yang dimainkan, upah yang rendah, skill yang tidak memadai merupakan situasi yang stagnan dan tidak menguntungkan bagi petani perempuan. Tidak heran osteoporosis pada petani perempuan menunjukkan angka yang mengenaskan, karena terlalu lama dalam posisi membungkuk dengan menggunakan sistem tradisonal bercocok tanam. ${ }^{13} \mathrm{Hal}$ ini diperparah dengan kondisi cuaca yang secara langsung berhadapan dengan mereka. Juga gizi yang buruk telah menyebabkan petani perempuan harus berhadapan dengan buramnya kesehatan mereka di hari tua.

$$
\text { Posisi ini cukup }
$$

menyudutkan petani perempuan. Mesin-mesin pertanian yang diciptakan saat ini pun masih didesain hanya untuk laki-laki,

13 Alfi Rahman, Petani Perempuan Aceh Tuntutan Profesi atau Keadaan?, tersedia pada http://suloh.or.id/index.php?option=com_frontp age\&Itemid=1. Diakses pada 29 Oktober 2008. contohnya adalah traktor tangan. Alat ini ternyata masih terbilang alat berat dan hanya dapat digunakan oleh petani laki-laki. Sedikit bertentangan dengan Engels, Ester Boserup mengatakan bahwa peningkatan teknologi pertanian justru telah merendahkan status perempuan, karena menyingkirkan akses perempuan terhadap kerja produktif. ${ }^{14}$

\section{Modal Sosial}

Selain SDM yang ia miliki, petani perempuan juga memiliki potensi yang besar dalam kegiatan pertanian yakni potensi modal sosial. Secara sederhana modal sosial dapat diartikan sebagai seperangkat nilai atau norma informal yang dimiliki bersama oleh anggota suatu kelompok yang memungkinkan kerjasama di antara mereka. $^{15}$ Jika anggota kelompok itu yakin bahwa anggota yang lain dapat dipercaya dan jujur, mereka akan saling percaya. Kepercayaan itu seperti pelumas yang membuat kelompok atau organisasi dapat dijalankan secara lebih efisien.

James Coleman, sosiolog yang menghidupkan kembali istilah modal sosial dalam tahun-tahun terakhir ini, mengatakan bahwa modal sosial adalah milik masyarakat dan karena itu cenderung dihasilkan dalam jumlah

\footnotetext{
${ }^{14}$ Ester Boserup, Women's Role in Economic Development, dalam Mansour Fakih, Analisis Gender dan Transformasi Sosial, Yogyakarta: Pustaka Pelajar, 2007, hlm. 61

${ }^{15}$ Francis Fukuyama, Guncangan Besar: Kodrat Manusia dan Tata Sosial Baru, Jakarta: Gramedia Pustaka Utama, 2005, hlm. 20.
} 
yang kurang oleh pasar bebas. ${ }^{16}$ Artinya modal sosial bermanfaat bagi masyarakat secara keseluruhan. Kelompok yang berpotensi menghasilkannya tidak dapat meraih manfaat modal sosial untuk dirinya sendiri, sehingga tidak mempunyai insentif yang memadai untuk menciptakannya. Oleh karena itu modal sosial harus diciptakan oleh kekuatan-kekuatan nonpasar baik oleh pemerintah maupun nonpemerintah, seperti keluarga atau bentuk-bentuk himpunan sukarela lainnya, seperti kelompok petani.

Untuk mengukur modal sosial secara memadai perlu memperhitungkan pula hakikat kerja sama yang dapat dilakukan oleh sebuah kelompok, kesulitankesulitan yang dihadapinya, nilai dari hasil kegiatannya, bisa tidak berjalan dalam kegiatan yang tidak menguntungkan, dan sebagainya ${ }^{17}$ sehingga dalam sebuah kelompok petani penggarap dapat diketahui bagaimana tingkat modal sosialnya.

Petani membentuk

kelompok-kelompok sendiri dalam mengerjakan lahan pertanian yang disebut kelompok petani penggarap. Sekelompok petani tersebut dapat disebut sebagai komunitas yang di dalamnya terdapat hubungan timbal balik. Seperti yang dikemukakan oleh Simmel yaitu sosiasi. Sosiasi adalah

16 James S. Coleman, Sosial Capital in the Creation of Human Capital, American Journal of Sociology, dalam Francis Fukuyama, Ibid., hlm. 313.

17 Ibid., hlm. 26 terjemahan dari bahasa Jerman Vergesellschaftung, yang secara harfiah berarti proses di mana masyarakat itu terjadi. ${ }^{18}$ Sosiasi meliputi interaksi timbal balik. Melalui proses ini dimana individu saling berhubungan dan saling mempengaruhi.

Modal sosial memiliki sifat yang berbeda dibandingkan dengan modal fisik atau manusia. Menurut ekonom Partha Dasgupta, modal sosial bukan milik masyarakat, tapi begitu sarat dengan eksternalitas. 19 Artinya tiap orang bisa saja menghasilkan modal sosial atas dasar kepentingan pribadi, tetapi bila telah dihasilkan, modal sosial akan menumpahkan banyak efek samping yang bermanfaat pada masyarakat yang lebih luas. Begitupun modal sosial yang memberikan kontribusi yang luar biasa dalam bidang pertanian melalui petani perempuan.

\section{Hasil Penelitian}

1. Kontribusi Petani Perempuan dalam Kehidupan Pertanian

a. Wujud Kontribusi Jumlah SDM petani perempuan di Desa Tegalrejo kurang lebih sepertiga dari total jumlah SDM petani secara keseluruhan, namun mereka mampu memberikan kontribusi

\footnotetext{
${ }^{18}$ Doyle Paul Jhonson, Teori Sosiologi Klasik dan Modern, Jakarta: Gramedia Pustaka Utama, 1994, hlm. 257.

${ }^{19}$ Partha Dasgupta, Economic Development and the Idea of Sosial Capital, dalam Francis Fukuyama, Guncangan Besar: Kodrat Manusia dan Tata Sosial Baru, Jakarta: Gramedia Pustaka Utama, 2005, hlm. 314.
} 
dalam bidang pertanian yang tidak kalah dengan petani laki-laki pada umumnya. Wujud kontribusi SDM yang mereka sumbangkan dalam bidang pertanian dapat dibagi menjadi enam, yaitu sebagai berikut:

1) Kontribusi Materi (Keuangan)

Kontribusi ini berupa sumbangan finansial (keuangan) yang mampu diberikan oleh petani perempuan dalam bidang pertanian maupun rumah tangganya. Sebenarnya petani perempuan tidak memiliki modal finansial yang cukup sebagai modal awal dalam membiayai kegiatan pertanian, sebab merekalah yang bekerja kemudian memperolah upah. Namun keterbatasan tersebut tidak menjadi penghalang bagi petani perempuan dalam berkontribusi.

Keuangan sangat

menentukan dalam segala hal termasuk dalam kegiatan pertanian. Bahkan dalam mengolah sawah pun petani membutuhkan dana yang tidak sedikit, seperti kebutuhan membeli benih, pupuk, obat pemberantas hama, dan lain-lain. Terlebih lagi mengingat hasil produksi pertanian baru dapat dinikmati selang kurang lebih 6 bulan sekali, dikarenakan petani di Desa Tegalrejo hanya mampu panen dua kali dalam setahun. Umumnya petani perempuan tidak mampu memberikan bantuan keuangan khususnya di awal kegiatan pengolahan sawah, akan tetapi mereka baru dapat berkontribusi dalam wujud materi setelah mereka memperoleh upah. Meskipun kecil, namun upah yang mereka dapatkan mampu

meningkatkan

perekonomian rumah tangganya.

2) Kontribusi Kepercayaan Memperoleh Kapital Meskipun petani perempuan belum mampu memberikan bantuan finansial dari hasil kerjanya namun mereka mampu mencukupi kebutuhan keuangan tersebut melalui cara lain. Petani perempuan di Desa Tegalrejo biasanya akan melakukan pinjaman keuangan pada lembaga-lembaga pertanian di desa atau pada kelompok arisan yang diikutinya atau bahkan pada lembaga-lembaga keuangan di luar desanya. Petani perempuan justru lebih mudah mengakses keuangan jika dibandingkan dengan petani laki-laki. Mereka lebih aktif dalam kegiatan sosial kemasyarakatan, dengan demikian mereka lebih mudah menjalin kemitraan dengan siapa saja khususnya lembagalembaga yang mampu memberikan bantuan dana dalam kegiatan pertanian maupun untuk kebutuhan rumah tangganya.

Saat petani mengalami kesulitan keuangan justru petani perempuanlah yang berperan besar disini. Berikut ini adalah hasil wawancara dengan ibu Ns seorang majikan yang turut bekerja di sawah bersama pekerjanya.

"Keuangan di rumah itu dipegang ibu mbak, jadi kalau ada kebutuhan pasti ibu yang memberikan persetujuan. Kalau keuangan sedang menipis biasanya ibu atau bapak pinjam uang keluar, tapi lebih sering ibu yang cari pinjaman. Perempuan itu kan lebih 
pinter negosiasi ketimbang bapakbapak." (sambil tertawa). ${ }^{20}$

Petani perempuan lebih kreatif dalam memikirkan keberlangsungan kegiatan pertaniannya dengan sesegera mungkin berusaha memperoleh dana guna memenuhi kebutuhan pertaniannya. Kelompok Tani maupun kelompok arisan yang diikuti ternyata mampu memberikan pinjaman dengan bunga lunak sesuai dengan kapasitas seorang petani untuk mengembalikannya. Banyak petani perempuan yang mampu berkontribusi dalam pengadaan dana melalui cara tersebut. Pengambilan keputusan yang bersifat teknis pertanian memang lebih banyak dilakukan oleh suami, sedangkan istri lebih dominan dalam pengambilan keputusan yang berkaitan dengan keuangan.

3) Kontribusi Menjalin Hubungan Sosial yang Harmonis

Petani perempuan di Desa Tegalrejo memiliki kepekaan sosial yang tinggi, khususnya pada sesama petani perempuan. Mereka menjalin hubungan yang harmonis baik dalam kegiatan mengolah sawah maupun dalam kehidupan sehari-hari. Masyarakat Desa Tegalrejo memiliki banyak kegiatan sosial di lingkungannya, adapun sebagian besar pelaku kegiatan sosial tersebut adalah kaum perempuan.

\footnotetext{
${ }^{20}$ Hasil wawancara dengan Ibu Ns, dilakukan pada hari Minggu, 19 April 2009, pkl. 16.0017.00. bertempat di kediaman Ibu Ns.
}

Membantu tetangga yang sedang hajatan merupakan salah satu contoh konkrit terciptanya hubungan sosial yang harmonis dalam masyarakat. Kegiatan ini dalam bahasa Jawa dikenal dengan istilah lagan. Lagan umumnya dilakukan oleh kaum perempuan, meskipun hanya memasak namun kegiatan ini bisa lebih dari lima hari berturut-turut. Bagi petani perempuan tentu saja harus bisa membagi waktu antara lagan, bekerja di sawah dan mengurus rumah tangga. Bahkan tidak jarang kaum petani perempuan yang merelakan waktu bekerjanya untuk membantu tetangga yang sedang hajatan.

Hubungan yang harmonis tersebut merupakan salah satu kontribusi yang diberikan oleh kaum petani perempuan. Secara tidak langsung kondisi tersebut mampu melahirkan situasi lingkungan yang harmonis secara berkelanjutan di lingkungan masyarakat Desa Tegalrejo, baik dalam kegiatan pertanian maupun dalam kegiatan sehari-hari. Berikut ini adalah pemaparan dari Ibu Drt mengenai upayanya dalam membagi peran, ketika harus membagi waktu antara lagan dan rutinitas lainnya.

"Ya disiapkan dari awal, kalau mau ada acara di luar ya yang lainnya harus dirikati dulu, tutur Ibu Drt."21

\footnotetext{
${ }^{21}$ Hasil wawancara dengan Ibu Drt. Pada hari Minggu, 19 April 2009. Pkl.19.00-19.30 WIB. Bertempat di rumah Ibu Drt.
} 
Ibu Drt dan petani perempuan pada umumnya selalu bekerja lebih maksimal ketika ada lagan maupun kegiatan lainnya. Mereka menyelesaikan pekerjaan rumah terlebih dahulu baru kemudian bergabung dengan kaum perempuan lainnya dalam kegiatan sosial tersebut.

4) Kontribusi

untuk

Melanjutkan Tradisi

Bertani/Kearifan Lokal

Kaum perempuan di Desa Tegalrejo yang bekerja sebagai petani memang masih sedikit, yakni hanya sepertiga dari keseluruhan jumlah SDM petani yang ada. Meskipun sudah berulang kali dihimbau oleh pemerintah desa namun masih banyak kaum perempuan menganggur yang enggan berkontribusi dalam kegiatan pertanian tersebut. Mereka masih menganggap bertani merupakan pekerjaan berat, kotor dan tidak berkelas. Justru kaum perempuan yang berkontribusi dalam kegiatan pertanian ini adalah mereka yang telah berumur 40 tahun keatas. Usia yang tidak lagi produktif untuk dipekerjakan di perusahaan dan industri/pabrik.

Banyak hal yang mendasari mereka untuk berkontribusi dalam bidang pertanian ini, salah satunya adalah kesadaran untuk melanjutkan tradisi bertani di lingkungan masyarakat. Jika bukan mereka, lalu siapa lagi yang akan mengerjakan sawahnya. Umumnya mereka yang telah berusia lanjut merasa kesepian di rumah dan berusaha mencari kesibukan, bertani menjadi pilihan yang tepat untuk mereka, dengan bertani mereka dapat mengisi waktu luang bahkan menambah penghasilan keluarga.

5) Kontribusi Tenaga Pertanian yang Ulet dan Disiplin

Baik petani laki-laki maupun petani perempuan sama-sama memberikan kontribusi berupa tenaga dalam bidang pertanian, perbedaannya terletak pada seberapa besar tenaga yang mampu mereka curahkan dalam pekerjaannya itu. Masyarakat umum beranggapan bahwa petani perempuan tidak begitu bertenaga, tenaga yang mereka miliki tidak sebanding jika dibandingkan dengan petani laki-laki. Namun hal ini akan bertolak belakang dengan kenyataan yang terjadi di Desa Tegalrejo. Saat musim mengolah sawah tiba, justru akan banyak didapati petani perempuan yang bekerja hingga menjelang malam. Itu artinya kontribusi tenaga yang mampu mereka berikan tidak kalah jika dibandingkan dengan petani laki-laki. Berikut ini adalah pemaparan Ibu Sk salah satu petani perempuan di Desa Tegalrejo:

"Menawi musim tandur, matun nopo malih wektu panen, ibu-ibu saged dugi peteng wonten sabin mbak. Mbawoni lajeng nenggo mobil sing badhe ngangkut pantun" (jika musim tanam, menyiang rumput apalagi musim panen, ibu-ibu bisa sampai petang berada di sawah Mbak. Menghitung perolehan padi kemudian menunggu mobil yang mengangkut padi).22

\footnotetext{
${ }^{22}$ Wawancara dengan Ibu Sk, dilakukan pada hari Minggu, 28 Desember, Pkl. 19.25-20.00 WIB. Bertempat di rumah Ibu Sk.
} 
Selain tenaga yang dimilki, ada sisi lain yang menjadikan seorang petani perempuan memiliki nilai lebih jika dibandingkan dengan petai laki-laki, yakni keuletan dan kedisiplinannya. Memang benar bahwa petani perempuan di Desa Tegalrejo terkenal dengan sosok yang ulet dan disipetani laki-lakiin. Petani perempuan yang mayoritas adalah petani penggarap selalu tepat waktu dalam setiap pekerjaannya, datang ke sawah memulai pekerjaan dan menyelesaikannya dalam waktu yang tepat bahkan mereka sangat menghargai waktu.

"Menawi nyambut damel kudu dirampungke gasik kanthi kasil sing apik. Yen matun sampun angsal sekothak tapi tesih padhang yo kudu disrempeng pindah kothak liyane. Nyambut gawe sing temen bakal oleh kasil sing sae". (Jika bekerja harus diselesikan dengan cepat dengan hasil yang baik. Ketika menyiang rumput sudah memperoleh hasil satu kothak tapi hari masih terang ya.. harus pindah ke kothak lainnya. Bekerja dengan sungguh-sungguh niscaya memperoleh hasil yang bagus). ${ }^{23}$

Sisa waktu yang sedikit mereka gunakan untuk memula pekerjaan yang lainnya, mereka tidak pernah menunda-nunda pekerjaan untuk hari berikutnya. Disamping itu petani perempuan juga jarang yang merokok, tidak seperti petani laki-laki pada umumnya. Pemilik sawah/majikan

23 Ibid. biasanya menyediakan rokok untuk para pekerjanya, baik untuk petani laki-laki maupun petani perempuan, siapa yang menginginkan maka bisa mengambilnya Rokok yang disediakan berupa rokok lintingan, yang ingin merokok harus meracik rokok terlebih dahulu, biasanya terdiri dari mbako/tembakau, gambir, menyan, klembak, cengkeh dan garet Meracik rokok lintingan membutuhkan waktu yang agak lama dan untuk merokok itu sendiri juga membutuhkan waktu yang tidak sedikit, selain itu pekerjaan yang dilakukan dengan disambi (diselingi) merokok juga tidak akan maksimal.

Petani perempuan biasanya akan langsung memulai pekerjaannya, sedangkan petani laki-laki membutuhkan waktu kurang lebih seperempat jam untuk merokok, artinya petani perempuan lebih disipetani laki-lakiin dalam memulai pekerjaan dan menyelesaikan pekerjaannya. Disamping itu hasil pekerjaan yang dilakukan oleh petani perempuan lebih rajin jika dibandingkan dengan petani laki-laki. Saat musim tandur (tanam), hasil pekerjaan petani perempuan akan lebih rajin, hal ini terlihat dari jarak tanaman yang sama dan teratur antara tanaman satu dengan yang lain. Saat musim matun (menyiang rumput), mereka juga bekerja dengan baik, hasilnya lebih bersih dan tanaman padi tidak banyak yang rusak.

6) Kontribusi Pikiran/Ide. 
Petani perempuan yang umumnya jarang berperan dalam ranah publik pertanian justru memiliki perhatian yang besar dalam bidang pertanian itu sendiri. Perhatian yang mereka tujukan disertai dengan ide-ide yang bagus dan kreatif serta menguntungkan bagi kegiatan pertanian. Seperti yang pernah dipaparkan oleh Bapak Kepala Desa Tegalrejo, Bapak Dmt, bahwa petani perempuan lebih cenderung terbuka dengan hal-hal yang baru seperti pembaruan pola tanam dan mekanisme pengolahan sawah lainnya.

Kaum petani perempuan lebih cenderung mapan untuk mencoba hal baru, salah satu contohnya adalah penggunaan pola tanam Jajar Legowo. ${ }^{4}$ Petani lakilaki tidak banyak yang bersedia menggunakan pola tersebut dengan alasan membutuhkan waktu yang lebih lama, bahkan mereka tidak lebih mahir menerapkan pola tanam Jajar Legowo dari petani perempuan.

Hasil produksi padi dengan pola tanam ini ternyata lebih tinggi jika dibandingkan dengan pola tanam biasa. Desa Tegalrejo juga termasuk dalam salah satu kawasan uji coba pola tanam Jajar Legowo ini dan hasilnya sangat memuaskan. Sampai saat ini petani perempuan di Desa Tegalrejo adalah petani yang paling menguasai pola Jajar Legowo. Petani laki-laki masih belum terampil menggunakan pola tersebut, mereka menganggap pola

\footnotetext{
${ }^{24}$ Hasil wawancara dengan Bapak Dmt pada hari Selasa, Tanggal 22 Desember 2008, pukul 13.00-15.00 WIB, di kediaman Bapak Dmt.
}

tersebut sulit dan memakan waktu yang lama.

Selain pola pikirnya yang lebih terbuka, petani perempuan juga lebih sering menyuarakan ideidenya dalam kegiatan pertanian. Seperti pada usulan dinaikkannya upah petani penggarap, pemenuhan kebutuhan pupuk dan pendistribusian pupuk yang merata dan tepat waktu. Sayangnya partisipasi petani perempuan dalam ranah publik masih minim.

Kegiatan penyuluhan, musyawarah Kelompok Tani dan penentuan kebijakan pertanian dalam lingkup desa sampai saat ini masih menjadi wilayah petani lakilaki saja. Petani perempuan belum diikutsertakan dalam kegiatan tersebut. Sehingga mereka hanya menyalurkan suaranya melalui suaminya atau petani laki-laki rekan kerja sesama petani penggarap lainnya. Tenyata ide-ide yang mereka berikan cukup beralasan dan layak dipertimbangkan bahkan sebagian besar usulan yang mereka berikan bernilai positif bagi produktivitas pertanian di Desa Tegalrejo.

\section{b. Proses Kontribusi}

Proses kontribusi dalam kegiatan pertanian merupakan sebuah rangkaian tindakan, perbuatan atau pengolahan yang dilakukan oleh petani khususnya petani perempuan yang menghasilkan produk pertanian maupun segala sesuatu yang berguna bagi keluarga dan masyarakat khusunya dalam bidang pertanian. Proses kontribusi yang dilakukan oleh petani perempuan 
ini dapat dibagi menjadi dua, yakni proses kontribusi dalam kehidupan rumah tangga petani dan proses kontribusi dalam kehidupan pertanian itu sendiri. Proses kontribusi yang kedua merupakan proses kontribusi yang dilakukan dalam cakupan yang lebih luas yakni masyarakat umum. Oleh sebab itu, proses kontribusi ini kemudian dibedakan menjadi dua dengan alur masing-masing berdasarkan cakupan wilayah kontribusinya.

1) Kontribusi dalam Rumah Tangga Petani

Seorang perempuan memiliki kewajiban utama dalam rumah tangga demikian halnya dengan seorang perempuan yang bekerja sebagai petani. Bagi perempuan yang hanya berperan sebagai ibu rumah tangga saja tentu akan memiliki waktu yang lebih banyak untuk mengatur rumah tangganya. Antara lain mengurus anak, memasak, membersihkan rumah, dan kegiatan rumah tangga lainnya.

Pekerjaan di sawah hampir menguras waktu petani perempuan selama satu hari penuh, oleh karena itu mereka lebih dahulu menyelesaikan kewajibannya di dalam rumah tangga sebelum berangkat ke sawah. Demikian kutipan wawancara dengan Ibu Sk:

"Kalau mau keluar (ke sawah atau mengikuti kegiatan di luar rumah lainnya), ya..yang di rumah sudah harus diberesi dulu. Pokoke kalau mau keluar, segala sesuatunya digasiki. (digasiki: segalanya dikerjakan lebih awal)" ${ }^{25}$

Rata-rata para ibu rumah tangga di Desa Tegalrejo mengawali rutinitas hariannya mulai pukul setengah lima pagi. Mereka lalu bersembahyang bagi yang muslim, sebuah ucapan syukur atas nikmat yang telah diberikan serta permohonan selamat untuk seluruh keluarganya tidak lupa untuk berkah tanaman padinya di sawah. Sebuah rutinitas harian yang diawali dengan ibadah tentu akan berbuah manis, demikian tentunya yang berada di dalam benak setiap ibu rumah tangga petani. Selesai beribadah biasanya ibu-ibu akan memasak untuk keluarganya, keluarga petani masih banyak yang menggunakan luweng26 untuk memasak, penggunaan luweng ini dapat menghemat pengeluaran untuk membeli minyak tanah di tengah kelangkaan yang terjadi.

Pukul setengah enam pagi, ibu-ibu petani sudah dapat menyediakan sarapan sederhana untuk anak-anak dan suaminya. Berdasarkan wawancara dengan beberapa informan, mereka tidak terbiasa dengan sarapan pagi, mereka lebih sering membungkus makanannya untuk dimakan di

\footnotetext{
${ }^{25}$ Wawancara dengan Ibu Sk, dilakukan pada hari Minggu, 28 Desember, Pkl. 19.25-20.00 WIB. Bertempat di rumah Ibu Sk.

${ }^{26}$ Luweng adalah tungku dengan kayu bakar sebagai bahan bakarnya. Tungku saat ini kembali diminati oleh penduduk semenjak kelangkaan minyak tanah. Selain itu di Desa Tegalrejo masih tersedia kayu bakar dalam jumlah yang banyak sehingga penggunaan tungku masih sangat efektif.
} 
sawah atau menunggu jatah makan dari pemilik sawah. Kegiatan mengurus rumah lainnya seperti mencuci piring, mencuci pakaian dan membersihkan rumah biasanya dapat mereka kerjakan hingga pukul 06.30 atau dengan bantuan anak-anak, setelah itu mereka bergegas ke sawah sebelum pukul 07.00.

Seorang petani perempuan akan merasa malu jika tiba di sawah kesiangan dan terlambat. Hal tersebut dinilai bahwa mereka tidak mampu mengurus rumah dengan baik. Pekerjaan di sawah menyita seluruh waktunya selama sehari penuh. Ketika mereka pulang ke rumah biasanya hari sudah petang, yakni pukul 16.00-17.00 WIB. Setibanya di rumah, mereka lalu membersihkan diri dan melanjutkan kewajiban lainnya sebagai ibu rumah tangga.

Menyiapkan makan malam, menemani anak-anak belajar dan merencanakan kebutuhan untuk esok paginya. Pukul 22.00 WIB biasanya seorang petani perempuan sudah mulai bersitirahat dari segala rutinitas hariannya. Meskipun mereka hanya sebagai petani penggarap namun mereka memiliki peran yang cukup penting baik di dalam rumah tangga petani itu sendiri maupun dalam kehidupan pertanian.

Berdasarkan hasil penerapan analisis Harvard pada petani perempuan di Desa Tegalrejo, profil aktivitas petani perempuan dalam kegiatan reproduksi (kehidupan rumah tangga) dapat dibagi menjadi delapan besar aktivitas, yaitu: a) terkait dengan air, b) terkait dengan bahan bakar, c) menyiapkan makan, d) mengasuh anak, e) Terkait dengan kesehatan, f) bersih-bersih, g) terkait dengan pasar, h) aktivitas sosial dengan tetangga.

2) Kontribusi dalam Pertanian Kontribusi petani perempuan dalam bidang pertanian ternyata tidak dapat diremehkan begitu saja, meskipun tenaga yang mereka miliki tidak sekuat petani laki-laki namun banyak dari mereka yang mampu memberikan kontribusinya secara maksimal seperti petani lakilaki pada umumnya bahkan lebih baik dari petani laki-laki. Petani rata-rata menghabiskan waktunya di sawah selama 9 jam/hari, yakni dari pukul 07.00-16.00 WIB. Namun terkadang mereka juga bisa pulang lebih awal atau bahkan hampir petang, hal ini tergantung pada kondisi dan musim pengolahan sawah. Jika musim tandur atau musim panen biasanya petani penggarap baru pulang ke rumah menjelang Maghrib yaitu sekitar pukul 17.30 WIB.

Berdasarkan hasil analisis Harvard diperoleh Sembilan aktivitas besar petani perempuan terkait dengan aktivitas produksi dalam pertanian, yaitu: menangkar benih; b) membajak/ mbrujul, c) membuat ler-leran, d) menyebar benih/ nyebar, e) mencabut benih/ ndaut, f) menanam/ tandur, g) menyiangi rumput/ matun I dan II, h) pemupukan/ ngrabuk, i) masa tenggang/ menunggu panen, j) panen.

Hampir seluruh kegiatan pertanian dari mulai menanam hingga memanen, petani 
perempuan berperan penuh di dalamnya. Selama musim panen, petani perempuan juga memiliki pekerjaan sambilan yaitu berjualan dawet di sawah. Es dawet ini ditujukan untuk para petani yang sedang memanen padi. Transaksi dilakukan dengan barter, yaitu kurang lebih satu besek ${ }^{27}$ padi akan memperoleh satu gelas es dawet. Begitu banyak upaya yang petani perempuan lakukan guna memenuhi kebutuhan keluarga dan masyarakat pada umumnya. Tidak berhenti sampai disitu saja, kegiatan penjemuran padi juga masih menjadi alur dalam proses kegiatan pertanian. Petani pemilik sawah biasanya akan meminta bantuan petani penggarap untuk menjemurkan padinya.

\section{c. Hasil Kontribusi}

Petani perempuan di Desa Tegalrejo ternyata mampu berkontribusi positif dalam kegiatan pertanian, tidak hanya rumah tangga mereka saja yang mampu dibangun akan tetapi perekonomian secara umum dan kesejahteraan masyarakat juga mampu mereka tingkatkan. Berikut ini adalah hasil kontribusi petani perempuan dalam bidang pertanian:

1) Perekonomian Keluarga Terangkat

2) Produksi

Pertanian Meningkat

27 Besek adalah wadah yang terbuat dari anyaman bambu berbentuk segi empat. Biasanya digunakan untuk tempat nasi saat diadakan kenduri.
3) Kesejahteraan Keluarga dan Masyarakat Meningkat

2. Faktor-faktor yang Mempengaruhi Kontribusi SDM Petani Perempuan dalam Kehidupan Pertanian

Kontribusi SDM yang mampu disumbangkan oleh petani perempuan dalam kehidupan pertanian di Desa Tegalrejo ini dipengaruhi oleh beberapa faktor, yakni faktor penghambat dan faktor pendukung, termasuk di dalamnya terdapat faktor internal (dari dalam diri) dan faktor eksternal (faktor dari luar/lingkungan).

a. Faktor Penghambat

Faktor yang dinilai menjadi penghambat kontribusi SDM petani perempuan di Desa Tegalrejo dapat diidentifikasi menjadi empat faktor yaitu: rasa percaya diri yang rendah, fisik yang lemah, beban kerja ganda, dan posisi petani perempuan yang termarginalkan dalam pengambilan keputusan di ranah publik serta akses dan kontrol yang rendah terhadap sumber daya pertanian yang ada.

b. Faktor Pendukung

Tersedianya SDM petani perempuan yang cukup banyak di Desa Tegalrejo ternyata tidak terlepas dari beberapa faktor yang mendukung baik faktor internal (dari dalam) maupun eksternal (dari luar/lingkungan). Faktor pendukung yang mendasari tingginya tingkat kontribusi SDM petani perempuan dalam kehidupan pertanian dapat diidentifikasi menjadi lima, yaitu: 
faktor ekonomi, banyaknya kegiatan sosial yang diiukti, kerjasama yang harmonis antar petani perempuan, interaksi yang terjalin baik antara petani perempuan dengan pihakpihak yang mendukung kegiatan pertanian, dan modal sosial yang mereka miliki.

\section{Kesimpulan}

Petani

perempuan merupakan SDM yang sangat berpengaruh dalam kehidupan pertanian di desa Desa Tegalrejo. Meskipun jumlahnya hanya sepertiga dari jumlah keseluruhan SDM petani yang ada, namun mereka memiliki kemampuan, keuletan dan kedisiplinan dalam berkontribusi di dalam kegiatan pertanian. Kontribusi yang mereka berikan dalam kegiatan pertanian dapat dibagi menjadi enam bagian, yaitu sebagai berikut: kontribusi keuangan, kontribusi kepercayaan memperoleh kapital, kontribusi untuk menjalin hubungan sosial yang harmonis, kontribusi melanjutkan tradisi bertani, dan kontribusi tenaga kerja petani yang ulet dan disiplin serta kontribusi ide dan pikiran.

Berdasarkan hasil penelitian terdapat beberapa hal yang teridentifikasi menjadi faktor penghambat kontribusi SDM petani perempuan, yaitu: rasa percaya diri yang rendah; fisik yang lemah; beban kerja ganda; posisi petani perempuan yang termarginalkan dalam pengambilan keputusan di ranah publik; serta akses dan kontrol yang rendah terhadap sumber daya pertanian yang ada.
Selanjutnya ada beberapa hal yang teridentifikasi menjadi faktor pendukung kontribusi SDM, yaitu: himpitan ekonomi; banyaknya kegiatan sosial yang diikuti; kerjasama yang harmonis antar petani perempuan; interaksi yang terjalin dengan baik antara petani perempuan dengan pihak-pihak yang mendukung kegiatan pertanian; serta modal sosial yang mereka miliki.

Alasan paling kuat yang mendorong kontribusi petani perempuan Desa Tegalrejo adalah himpitan ekonomi keluarga, selain itu petani perempuan mulai berusaha untuk ikut aktif dalam kegiatan penyuluhan dan musyawarah kelompok tani. Hal ini sekaligus sebagai temuan baru, bahwa kontribusi dalam bidang pertanian tidak selalu harus turun ke sawah. Membantu dalam kegiatan musyawarah kelompok tani dan berbagai agenda pertanianpun sudah merupakan sebuah kontribusi yang sangat berarti bagi keberlangsungan kehidupan pertanian di Desa Tegalrejo.

Masih banyaknya potensi petani perempuan yang belum terrangkum dalam ranah publik ternyata menjadi kendala utama bagi upaya peningkatan kontribusi SDM petani perempuan dalam bidang pertanian di Desa Tegalrejo. Meskipun demikian, keberadaan petani perempuan di Desa Tegalrejo telah mampu membawa kemajuan (progress) bagi kehidupan pertanian itu sendiri, yakni mampu meningkatkan produktivitas pertanian, meningkatkan 
perekonomian keluarga/rumah tangga petani dan meningkatkan kesejahteraan masyarakat secara umum.

Hasil penelitian ini juga mematahkan argumen bahwa perempuan sebagai the second sex, dimana mereka selalu kalah jika dibandingkan dengan laki-laki. Namun kenyataannya tidak demikian bagi petani perempuan di Desa Tegalrejo. Masalah fisik dan tenaga adalah permasalahan individu yang memang menjadi momok bagi setiap pekerjaan yang mengutamakan kekuatan fisik dan tenaga, akan tetapi petani perempuan di Desa Tegalrejo mampu mengatasinya dengan baik. Disiplin dan menghargai waktu dalam bekerja, dua hal tersebut telah menjadi nilai lebih bagi para petani perempuan di Desa Tegalrejo.

Selain itu petani perempuan lebih solid dalam membina hubungan kerja. Hal ini dapat dilihat dari cepatnya informasi yang menyebar melalui hubungan yang terjalin antar petani perempuan, salah satunya adalah informasi pekerjaan. Petani perempuan akan mengetahui siapa saja majikan yang membutuhkan tenaganya dari sesama petani perempuan lainnya.

Penelitian ini menarik kesimpulan bahwa kontribusi petani perempuan dalam kegiatan pertanian merupakan faktor yang sangat menentukan dalam keberhasilan dan produktivitas pertanian itu sendiri. Hasil kontribusinya juga memberikan manfaat yang sangat besar bagi dirinya, keluarga, masyarakat dan negara. Adapun permasalahan minimnya minat perempuan dalam berkontribusi dalam kegiatan pertanian tidak selayaknya jika hanya dipandang sebelah mata, namun permasalahan ini harus segera diatasi dengan baik, mengingat masih banyak wilayah pertanian yang selalu mengimpor tenaga dari luar akibat kurangnya tenaga pertanian dari dalam wilayahnya.

\section{Daftar Pustaka}

Anwar. Manajemen Pemberdayaan Perempuan: Perubahan Sosial Melalui Pembelajaran Vocational Skill pada Keluarga Nelayan, Bandung: Alfabeta,

Doyle Paul Jhonson, Teori Sosiologi Klasik dan Modern, Jakarta: Gramedia Pustaka Utama, 1994.

Faustino Cardoso Gomes, Manajemen Sumber Daya Manusia, Yogyakarta: Andi, 2003.

Francis Fukuyama, Guncangan Besar: Kodrat Manusia dan Tata Sosial Baru, Jakarta: Gramedia Pustaka Utama, 2005.

Ja Noertjahyo, Dari Ladang Sampai Kabinet: Menggugat Nasib Petani, Jakarta: Penerbit Buku Kompas, 2005.

Ken Suratiyah, dkk, Dilema Wanita Antara Industri Rumah Tangga dan 
| Ruri Purnamawati

Aktivitas Domestik. Yogyakarta: Eksploitasi Perempuan Usaha Mikro di Aditya Media, 1996. Perdesaan Jawa, Bandung: Akatiga, 2004.

Mansour Fakih, Analisis Gender dan Transformasi Sosial, Yogyakarta: Pustaka Pelajar, 2007.

Trisakti Handayani dan Sugiarti, Konsep dan Teknik Penelitian Gender, Malang: UMM Press, 2006.

Ratih Dewayanti dan Erna

Ermawati Chotim, Marginalisasi dan 